\title{
Model Pendidikan Karakter Pada Anak Usia Dini Melalui Program Islamic Habituation
}

\author{
Widyaning Hapsari, itsna iftayani \\ Universitas Muhammadiyah Purwokerto \\ hapsariazhar@gmail.com ${ }^{1}$ itsnaiftayani@gmail.com $^{2}$
}

\begin{abstract}
Abstrack. The planting of characters in preschool age is an important thing to do. Formation effort character according to the nation's culture is certainly not only be done in school through a series of learning activities, but also with habituation (habituation) in life include: religiosity, honesty, discipline, tolerance, responsibility. The aim this research is to apply the model of character education in early childhood through Islamic habituation in kindergarten Aisha Surakarta. This research is an applied research that produces the product in the form of character education model in early childhood. Data collected through observation and interviews were analyzed with descriptive qualitative and quantitative. The results of the research data analysis is the Islamic Habituation program can be accepted by the school and students and guardians. In addition, opportunities for the implementation of the program very well so that it can be said that the Islamic habituation program feasible. Character education activities in the form of habituation Islamic program includes several phases: the preparation phase of the program, socialization, planning, implementation, evaluation, development.
\end{abstract}

Keywords: character education, early childhood, islamic habituation

Abstrak. Penanaman karakter di usia prasekolah merupakan hal yang penting untukdilakukan. Upaya pembentukan karakter sesuai dengan budaya bangsa ini tentu tidak semata dilakukan di sekolah melalui serangkaian kegiatan belajar mengajar, akan tetapi juga dengan pembiasaan (habituasi) dalam kehidupan yang mencakup: religiusitas, kejujuran, kedisiplinan, toleransi, tanggung-jawab. Tujuan peneltian ini adalah untuk menerapkan model pendidikan karakter pada anak usia dini melalui Islamic Habituation di Taman Kanak-kanak Aisyah Surakarta. Penelitian ini merupakan penelitian terapan yang menghasilkan produk berupa model pendidikan karakter pada anak usia dini. Data yang terkumpul melalui metode observasi dan wawancara dianalisis dengan deskriptif kualitatif dan kuantitatif. Hasil analisis data penelitian adalah program Islamic Habituation dapat diterima oleh pihak sekolah beserta siswa dan wali murid. Selain itu, peluang untuk diimplementasikannya program sangat baik sehingga dapat dikatakan bahwa program Islamic Habituation layak diterapkan. Kegiatan pendidikan karakter berupa Program Islamic Habituation meliputi beberapa tahap yaitu: tahap penyusunan program, sosialisasi, perencanaan, pelaksanaan, evaluasi, pengembangan.

Kata kunci: anak usia dini, islamic habituation, pendidikan karakter

\section{PENDAHULUAN}

Fungsi pendidikan di Taman Kanak-kanak adalah mengenalkan peraturan dan menanamkan disiplin, mengenalkan anak dengan dunia sekitar, menumbuhkan sikap dan perilaku yang baik, mengembangkan kemampuan berkomunikasi dan 
bersosialisasi, serta menyiapkan anak untuk memasuki pendidikan dasar (Miftahudin, 2011). Pengembangan potensi pada anak tidak hanya dari sisi intelektual saja, tetapi juga mengembangkan sikap, emosi, termasuk mengembangkan karakter anak didik. Mengingat usia prasekolah merupakan masa persiapan untuk sekolah yang sesungguhnya, maka penanaman karakter yang baik di usia prasekolah merupakan hal yang sangat penting untuk dilakukan.

Salah satu aspek pendidikan karakter pada anak yang diperlukan adalah penanaman sikap disiplin. Kedisiplinan sangat penting diajarkan demi tercapainya kehidupan yang sesuai norma, sehingga anak dapat membedakan perbuatan baik dan buruk sebagai makhluk sosial (Aristowati, 2012). Disiplin yang dimiliki siswa akan membantu siswanya dalam bertingkah laku sehari-hari, baik di sekolah maupun di rumah. Siswa akan mudah menyesuaikan diri dengan lingkungan yang dihadapinya. Aturan yang terdapat di sekolah akan dilaksanakan dengan baik jika siswa sudah memiliki disiplin dalam dirinya. Kedisiplinan sebagai alat pendidikan diterapkan dalam rangka pembentukan, pembinaan dan pengembangan sikap serta tingkah laku yang baik. Sikap dan tingkah laku yang baik tersebut dapat berupa kerajinan, berbudi pekerti luhur, patuh, hormat, tenggang rasa dan berdisiplin. Kedisiplinan dapat mengarahkan siswa untuk menyesuaikan diri dengan cara menaati tata tertib sekolah. Berfungsinya kedisiplinan sebagai alat pendidikan dan alat menyesuaikan diri akan mempengaruhi berlangsungnya kegiatan belajar mengajar di sekolah. Di sekolah yang kedisiplinannya baik, kegiatan belajar mengajar akan berlangsung tertib, teratur, dan terarah. Sebaliknya di sekolah yang kedisiplinannya rendah maka kegiatan belajar mengajar juga akan berlangsung tidak tertib, sehingga mengurangi kualitas pendidikan di sekolah tersebut.

Upaya pembentukan karakter sesuai dengan budaya bangsa ini tentu tidak semata-mata hanya dilakukan di sekolah melalui serangkaian kegiatan belajar mengajar dan luar sekolah, akan tetapi juga dengan pendekatan pembiasaan (habituasi) dalam kehidupan yang mencakup: religiusitas, kejujuran, kedisiplinan, toleransi, tanggung-jawab, dan sebagainya. Pembiasaan bukan hanya mengajarkan pengetahuan tentang halhal yang benar dan salah, akan tetapi juga mampu merasakan nilai yang baik dan tidak baik, serta bersedia melakukannya dari lingkup terkecil seperti keluarga sampai dengan cakupan yang lebih luas di masyarakat.

Berkaitan dengan masalah kedisiplinan siswa, hasil tinjauan di lapangan menunjukan bahwa hal tersebut masih menjadi permasalahan di TK Aisyah. Menurut keterangan dari guru, banyak siswa yang kurang dapat menunjukan sikap tertib saat kegiatan di sekolah. Beberapa kegiatan yang tidak diikuti siswa dengan tertib adalah pada saat berbaris, berdoa bersama, dan saat guru memberikan materi atau penjelasan kegiatan. Ketidaktertiban siswa ditunjukan dengan bercanda, mengobrol atau melakukan aktivitas lain. Sementara itu, dari hasil wawancara dengan wali murid, diketahui bahwa anaknya yang saat ini duduk di kelas B memang sering terlambat datang ke sekolah karena bangun kesiangan. Terkadang anaknya juga rewel ketika diajak pergi karena meminta sesuatu.

Berdasarkan hasil angket yang ditujukan pada guru dan wali murid, didapatkan informasi mengenai perilaku anak di sekolah dan 
kesehariannya di rumah. Angket yang ditujukan pada guru menunjukan hasil bahwa perilaku ketidakpatuhan siswa adalah pada saat berdoa, saat guru memberikan materi, saat sholat berjamaah, dan saat berbaris. Selain itu, dalam menggunakan fasilitas sekolah siswa kurang dapat menunjukan tanggung jawabnya. Menurut guru, upaya yang dapat dilakukan guru yaitu memberikan keteladanan dalam berperilaku, dan bersikap tegas agar anak terbiasa dengan kedisiplinan.Sedangkan berdasarkan hasil angket yang diberikan pada orang tua diketahui bahwa ketidadisiplinan yang sering terjadi adalah masalah ketidaktepatan waktu datang ke sekolah. Beberapa orang tua mengungkapkan bahwa anaknya sulit dinasehati, dan sering rewel. Orang tua berharap guru di sekolah dapat meningkatkan kreativitas dalam mengajar, menanamkan disiplin pada anak, dan mengajarkan praktek ibadah.

Berdasarkan hasil pengamatan yang bertujuan melihat sikap disiplin siswa di TK Aisyah, diketahui bahwa siswa masih belum menunjukan sikap disiplin di sekolah. Hal tersebut terlihat baik di luar maupun ketika kegiatan belajar di kelas. Banyak siswa yang datang tidak tepat waktu, yaitu saat kegiatan berbaris sudah dimulai. Pada saat berbaris, hanya sebagian siswa saja yang mampu mengikuti kegiatan dengan tertib, sementara sebagian yang lain bercanda dengan temannya. Siswa juga sulit untuk bersikap tenang ketika di kelas. Dilihat dari usia siswa, hal tersebut merupakan sesuatu yang wajar, namun jika dibiarkan maka dapat mengganggu ketertiban kelas. Suasana belajar menjadi tidak nyaman, anak sulit berkonsentrasi, bahkan tujuan pembelajaran tidak akan tercapai.
Adapun salah satu faktor yang menyebabkan perilaku tidak disiplin pada siswa adalah proses pembelajaran oleh guru yang cenderung berorientasi pada pencapaian target yang ditetapkan sehingga kurang memperhatikan tentang penanaman disiplin positif pada siswa. Kegiatan pembelajaran yang ada di TK Aisyah mengacu pada kurikulum diknas yang berintegrasi dengan nilai keagamaan, namun berlangsung secara monoton sehingga kurang menarik bagi siswa dan menyebabkan siswa kurang fokus. Proses pembelajaran merupakan salah satu komponen dari sistem yang ada di TK Aisyah dalam menjalankan fungsinya sebagai institusi pendidikan. Oleh karenanya, kelemahan yang terdapat pada proses pembelajaran tentu akan menghambat berfungsinya TK Aisyah secara keseluruhan sehingga tujuan atau visi misi tidak dapat tercapai dengan optimal.

Faktor selanjutnya yang didapatkan dari hasil observasi dan wawancara yaitu perbandingan yang tidak seimbang antara jumlah guru dan siswa sehingga menyulitkan guru dalam mengendalikan perilaku siswa yang kurang tertib. Hanya ada satu guru di kelas B yang dapat memimpin kegiatan berdoa dan hafalan, sehingga semua siswa kelas B harus digabung. Selanjutnya, minimnya contoh perilaku dari guru juga merupakan penyebab siswa kurang dapat mematuhi guru. Beberapa guru sering datang terlambat ke sekolah, yaitu setelah siswa-siswa datang. Perilaku guru yang kurang disiplin tersebut sangat mungkin menjadikan siswa kurang memiliki keinginan untuk datang tepat waktu ke sekolah. Dalam menerapkan kedisiplinan pada siswa, guru tidak memiliki cara-cara khusus sehingga sikap guru-guru pada siswa berbeda satu sama lain. Kebanyakan guru 
hanya menegur siswa apabila ia membuat suatu kesalahan dalam perilakunya tanpa memberi pengertian mendalam.

Kurangnya pengetahuan guru dalam memahami perilaku anak menyebabkan guru cenderung menerapkan kedisiplinan yang kurang tepat, misalnya dengan menerapkan hukuman fisik, mengancam dan membentak ketika siswa melakukan perilaku negatif. Hasil observasi menunjukan bahwa salah satu guru masih menerapkan hukuman fisik, mengancam dan membentak ketika siswa melakukan perilaku negatif. Sebagian besar guru tidak pernah mendapatkan pembelajaran mengapa anak bertingkah laku tidak benar dan bagaimana menerapkan kedisiplinan pada anak berdasarkan perilakunya tersebut. Rasa frustrasi karena perilaku anak yang tidak wajar dan minimnya kemampuan untuk menangani hal tersebut menjadikan beberapa guru bertindak keras terhadap anak dengan memberikan hukuman fisik atau caci maki sebagai bentuk hukuman emosional bagi anak. Hal-hal tersebut di atas terjadi dikarenakan belum adanya aturan khusus atau standar acuan yang mengatur perilaku guru maupun siswa di sekolah. Standar yang dapat mengatur perilaku guru dan siswa dapat diterapkan atau diaplikasikan dalam kegiatan pembelajaran yang dilakukan secara konsisten.

Sebelum menerapkan metode yang tepat untuk menanamkan kedisiplinan pada siswa, guru perlu menumbuhkan komitmen untuk bersama mengembangkan sikap kedisiplinan siswa dengan meningkatkan kompetensi serta pengetahuan mengenai anak usia dini. Hal tersebut sebagai upaya untuk membangun suatu hubungan yang postif dengan semua siswa agar tumbuh perasaan nyaman dari para siswa. Dengan demikian, program yang bertujuan untuk menerapkan disiplin para siswa melalui konsep pembiasaan pun akan lebih efektif karena siswa dapat melakukannya dengan senang hati.

Adapun tujuan dari peneltian ini adalah mengetahui efektivitas program Islamic habituation untuk menanamkan karakter kedisiplinan pada siswa di TK Aisyah. Hasil dari penelitian ini diharapkan dapat memberi manfaat antara lain yaitu memberi sumbangan pemikiran bagi lembaga pendidikan pada umumnya dan bagi TK Aisyah pada khususnya, memberikan alternatif strategi pengembangan lingkungan pembelajaran yang ramah bagi anak sehingga anak dapat menunjukan kepatuhan dengan senang hati.

Disiplin merupakan cara orang tua mengajarkan kepada anak tentang perilaku moral yang dapat diterima kelompok. Tujuan utamanya adalah memberitahu dan menanamkan pengertian dalam diri anak tentang perilaku yang baik dan buruk, serta untuk mendorongnya memiliki perilaku sesuai dengan standar yang ada (Leman, 2009). Disiplin dapat diartikan sebagai suatu keadaan tertib dimana orang-orang yang tergabung dalam suatu sistem tunduk pada suatu system peraturan.Disiplin merupakan kesadaran diri yang muncul dari batin terdalam untuk mengikuti dan menaati peraturan-peraturan, nilai-nilai dan hukum-hukum yang berlaku dalam suatu lingkungan. Kesadaran itu antara lain, apabila dirinya berdisiplin baik maka akan memberi dampak yang baik bagi keberhasilan dirinya pada masa depan (Mulyasa, 2003). Disiplin bukan hanya berkaitan dengan ketepatan waktu namun juga pembentukan pribadi anak. Mendisiplinkan dapat berarti langsung menanamkan norma sebagai input yang biasanya dilakukan melalui instruksi. Menanamkan norma 
dengan cara itu akan menjadikan anak patuh, tetapi tanpa kesadaran akan tanggung jawab. Berbeda halnya jika pendisiplinan tersebut dilakukan secara bertahap (nilai terlebih dahulu untuk membuka kesadaran) kemudian menanamkan norma yang telah disepakati bersama. Pendisiplinan seperti ini akan membentuk anak taat dan bertanggung jawab (John, 2011).

Ditinjau dari sudut pandang sosiologis dan psikologis, disiplin adalah suatu proses belajar yang mengembangkan kebiasaan, penugasan diri, dan mengakui tanggung jawab pribadinya terhadap masyarakat. Maka kedisiplinan peserta didik dalam mengikuti suatu kegiatan pun akan menimbulkan sikap tanggung jawab, atau disiplin dalam menghadapi pelajaran dan dalam belajarnya. Dengan demikian indikator disiplin di sekolah dapat dilihat dalam proses dan hasil belajar. Dalam proses belajar indikatornya dapat dilihat dari: kehadiran di kelas, motivasi belajar, partisipasi dalam kelas, etika dan sopan santun, kerapian berpakaian, belajar beberapa jam setiap hari, menyimak dengan sungguh-sungguh setiap pelajaran, dan mencapai Standar Ketuntasan Belajar Minimal (SKBM).

Menurut Bandura (dalam Rahmayani, 2013), modeling adalah proses belajar dengan mengamati tingkah laku atau perilaku dari orang lain. Modeling artinya meniru, yang berarti proses pembelajaran dengan melihat dan memperhatikan perilaku orang lain kemudian mencontohnya. Hasil dari modeling atau peniruan tersebut cenderung sama dengan perilaku modelnya, sehingga modeling merupakan bagian yang sangat penting pada proses pembelajaran. Terdapat empat proses yang terlibat dalam pembelajaran melalui pendekatan modeling yaitu attention, retention, reproduction, motivation.

Dapat didefinisikan bahwa metode keteladanan (uswah) adalah metode pendidikan yang diterapkan dengan cara memberi contoh-contoh (teladan) baik yang berupa prilaku nyata, khusunya ibadah dan akhlak (Ramadhan, 2012). Metode keteladanan memiliki peranan yang sangat signifikan dalam upaya mewujudkan pendidikan anak usia dini, dimana selain diajarkan secara teoritis peserta didik juga bisa melihat secara langsung bagaimana praktik atau pengamalan dari pendidiknya yang kemudian bisa dijadikan teladan atau contoh dalam berperilaku dan mengamalkan atau mengaplikasikan materi pendidikan yang telah dia pelajari selama proses belajar menganjar.

Strategi pembiasaan untuk membentuk perilaku disiplin siswa di pendidikan usia dini dapat dilakukan dengan menggunakan metode pemodelan sesuai dengan prinsipprinsip teori belajar. Kebiasaan disiplin siswa dapat dibentuk dengan kegiatan rutin dan kegiatan spontan, dimana guru menjadi sumber pembelajar yang utama karena berperan sebagai model bagi para siswa. Keteladanan (modeling) adalah perilaku dan sikap guru dalam memberikan contoh terhadap tindakan-tindakan yang baik sehingga diharapkan menjadi panutan bagi anak. Jika guru dan tenaga kependidikan menghendaki agar anak berperilaku dan bersikap sesuai dengan nilai-nilai karakter bangsa, maka seharusnya merekalah orang pertama dan utama yang memberikan contoh perilaku dan sikap sesuai dengan nilai-nilai itu.Misalnya, berpakaian rapi, datang tepat waktu, bekerja keras, bertutur kata sopan, menunjukan kasih sayang, perhatian terhadap peserta didik, jujur, menjaga 
kebersihan. Anak-anak pada usia 4-6 tahun, sudah dapat menerima pandangan orang lain, terutama orang dewasa. Anak bisa menghormati otoritas dan sangat mempercayai orang tua atau guru, sehingga penekanan pentingnya perilaku baik dan sopan akan sangat efektif. Keteladanan guru pada saat bersalaman pagi di gerbang sekolahyang rutin dilakukan, untuk menyambung kasih sayang. Guru memberikan keteladanan dengan menyambut kedatangan anak di depan pintu gerbang, serta memberi yang akan dibalas dengan salam dan mencium tangan guru oleh siswa. Kemudian guru memberikan afirmasiafirmasi positif, menghargai setiap gerak perubahan perilaku anak, sebagai upaya penguatan agar anak lebih termotivasi memunculkan perilaku baiknya. Guru juga tersenyum dan menyambut pengantar atau orang tua yang mengantar putra-putrinya. Hal ini sekaligus untuk meyakinkan bahwa putra-putri mereka aman bersama guru-guru di sekolah. Kegiatan pagi yang sederhana tersebut dimaksudkan untuk menumbuhkan rasa hormat kepada orang tua, nilai-nilai kebersamaan, peduli dan rasa sayang terhadap sesama. Hal tersebut dicontohkan langsung oleh guru sebagai sosok panutan bagi anak. Kegiatan-kegiatan yang mengandung unsur keteladanan, dapat diimplementasikan dalam kegiatan belajar mengajar di sekolah agar siswa terbiasa melakukannya secara mandiri nantinya. Perlahan-lahan sikap atau nilai-nilai luhur yang ditanamkan guru tersebut akan terinternalisasi ke dalam diri siswa dan membentuk kesadaran sikap dan tindakan sampai usia dewasa. Kegiatan-kegiatan yang bertujuan membentuk kebiasaan melalui modeling tersebut dilakukan oleh lingkungan sekolah yaitu kepala sekolah, guru, tenaga kependidikan dan murid bersama-sama sebagai suatu komunitas untuk membuat komitmen bersama dalam membiasakan budaya positif di lingkungan sekolah.

Terkait dengan pananaman nilai kedisiplinan melalui modeling yang diimplementasikan dalam pembelajaran aktif, setiap satuan pendidikan dapat mengefektifkan alokasi waktu yang tersedia. Hal ini dapat dilakukan sejak guru mengawali pembelajaran, selama proses berlangsung, pemberian tugas-tugas mandiri dan terstruktur secara individual maupun berkelompok, serta penilaian proses dan hasil belajar. Strategi dapat dilakukan sejak awal datang di sekolah, yaitu anak dibiasakan untuk saling menyapa, mengucapkan salam ketika bertemu sesama mereka dan guru. Di pagi hari, guru menyambut siswa dengan sapaan, senyum dan salam.

Jam belajar yang lebih awal selama 30 menit dapat dimanfaatkan untuk melakukan kegiatan rutin seperti doa bersama, kultum, atau kegiatan lain yang relevan. Dalam rangka pembiasaan, di berbagai sekolah juga dilakukan pelaksanaan ibadah dengan memanfaatkan waktu istirahat. Untuk kegiatan ekstrakurikuler dapat dilakukan pada hari Sabtu. Beberapa strategi penambahan waktu pembelajaran yang dapat dilakukan, misalnya:

1. Kegiatan bersih lingkungan selama 20 menit pada hari Jum'at sebelum memulai KBM

2. 20 menit di pagi hari untuk membangun motivasi siswa dengan melakukan kegiatan yang menyenangkan

3. Olahraga atau senam setiap hari Sabtu selama 30 menit di awal 
4. Meluangkan waktu untuk belajar iqro' selama 30 menit untuk masing-masing kelas

5. Makan bersama selama 15 menit saat istirahat

6. Kegiatan ekstra setiap hari Sabtu selama 30-45 menit Untuk mengukur tingkat keberhasilan pelaksanaan program di satuan pendidikan dilakukan melalui berbagai penilaian dengan membandingkan kondisi awal dengan pencapaian dalam waktu tertentu. Penilaian keberhasilan tersebut

\section{METODE PENELITIAN}

Metode penelitian yang dipergunakan adalah metode penelitian danpengembangan atau Research \& Development (R\&D). Metode penelitian danpengembangan merupakan metode yang dipergunakan untuk menghasilkan suatuproduk dan menguji keefektifan produk tersebut sesuai dengan tujuanpengembangan. Produk yang dihasilkan dari penelitian dan pengembangan ini adalah prototype model pendidikan karakter pada anak usia dini melalui Islamic Habituation. Metode yang dipergunakan meliputi metode deskriptif dan evaluatif. Metode deskriptif dipergunakan untuk menghimpun kondisi yang ada di lapangan. Metode evaluatif dipergunakan untuk mengevaluasi kelayakan model. Melalui evaluasi produk dan proses uji coba tersebut diharapkan dapat diperoleh masukantentang kelebihan-kelebihan dan kekurangan-kekurangan dari produk. Pengembangan model pendidikan karakter pada anak usia dilakukan melalui langkah-langkah berikut:

1. Mengembangkan indikator dari nilai-nilai yang ditetapkan atau disepakati

2. Menyusun berbagai instrumen penilaian

3. Melakukan pencatatan terhadap pencapaian indikator

4. Melakukan analisis dan evaluasi

5. Melakukan tindak lanjut

dini melalui Islamic Habituationd alam bentuk penerapan program Islamic habituation di TK Aisyah selama satu semester. Sedangkan metode evaluasi dilakukan dengan metode observasi, wawancara dan kuesioner. Penelitian dilaksanakan di TK Aisyah Pabelah Surakarta.

\section{HASIL DAN PEMBAHASAN}

Langkah-langkah pelaksanaan program Islamic Habituation:

1. Tahapan Pengembangan

Pelaksanaan pendidikan karakter di satuan pendidikan perlu melibatkan seluruh warga sekolah dan orang tua siswa. Prosedur pengembangan kurikulum yang mengintegrasikan pendidikan karakter pada satuan pendidikan dilakukan melalui tahapan perencanaan, pelaksanaan, evaluasi, dan pengembangan.

2. Sosialisasi
a. Melaksanakan
sosialisasi program dan melakukan komitmen bersama antara 
seluruh komponen warga sekolah atau satuan pendidikan (stakeholder).

b. Membuat komitmen dengan semua stakeholder (seluruh warga sekolah, orang tua siswa, komiteuntuk mendukung pelaksanaan program.

3. Perencanaan

a. Melakukan analisis konteks terhadapkondisi sekolah/satuan pendidikan (internal dan eksternal) yang dikaitkan dengan nilai-nilai kedisiplinan yang akan dikembangkan pada satuan pendidikan yang bersangkutan. Analisis ini dilakukan untuk menetapkan nilai-nilai dan indikator keberhasilan yang diprioritaskan, sumber daya, sarana yang diperlukan, serta prosedur penilaian keberhasilan.

b. Menyusun rencana aksi sekolah/satuan pendidikan berkaitan dengan penetapan nilai-nilai kedisiplinan.

c. Membuat program perencanaan dan pelaksanaan penanaman disiplin serta memasukkan karakter utama yang telah di tentukan dalam:

- Pengintegrasian melalui pembelajaran

- Pengintegrasian melalui muatan lokal

d. Membuat perencanaan pengkondisian, seperti:

- Penyediaan sarana

- Keteladanan

- Penghargaan

dan pemberdayaan
- Penciptaan kondisi atau suasana sekolah atau satuan pendidikan

e. Mempersiapkan guru melalui workshop dan pendampingan

4. Pelaksanaan

Melakukan penyusunan kurikulum yang memuat pengembangan nilainilai kedisiplinan.

a. Mendata kondisi dokumen awal (mengidentifikasi nilai-nilai kedisiplianan sesuai dengan karakter bangsa dalam dokumen I)

b. Merumuskan nilai-nilai kedisiplinan di dalam Dokumen I (latar belakang pengembangan KTSP, Visi, Misi, Tujuan Sekolah atau satuan pendidikan, Struktur dan Muatan Kurikulum, Kalender Pendidikan, dan program Pengembangan Diri atau pengembangan kepribadian profesional)

c. Mengembangkan peta nilai yang telah terpilih dari tahun pertama sampai tahun terakhir satuan pendidikan

d. Mengitengrasikan nilai-nilai kedisiplinan yang telah terpetakan dalam dokumen II (silabus dan RPP)

e. Melakukan pengkondisian, seperti:

1) Penyediaan sarana

2) Keteladanan

3) Penghargaan dan pemberdayaan

f. Penciptaan kondisi atau suasana sekolah

g. Mempersiapkan guru melalui workshop dan pendampingan

5. Evaluasi 
a. Melakukan

penilaian

keberhasilan dan supervisi

Untuk

keberlangsungan

pelaksanaan pendidikan karakter

perlu dilakukan penilaian keberhasilan dengan

menggunakan indikator-indikator berupa perilaku semua warga dan kondisi sekolah/satuan pendidikan yang teramati. Penilaian ini dilakukan secara terus menerus melalui berbagai strategi. Supervisi dilakukan mulai dari menelaah kembali perencanaan, kurikulum, dan pelaksanaan semua kegiatan yang berkaitan dengan penanaman sikap disiplin, yaitu:

b. Implementasi program pengembangan diri berkaitan dengan pengembangan nilai pendidikan budaya dan karakter bangsa dalam budaya sekolah atau sataun pendidikan.

c. Kelengkapan sarana dan prasarana pendukung implementasi pengembangan nilai kedisiplinan sesuai karakter bangsa

d. Implementasi nilai-nilai kedisiplinan dalam pembelajaran

e. Implementasi belajar aktif dalam kegiatan pembelajaran

f. Ketercapaian Rencana Aksi Sekolah/satuan pendidikan berkaitan dengan penerapan nilai-nilai kedisiplinan

g. Penilaian penerapan nilai kedisiplinan pada pendidik, tenaga kependidikan, dan peserta didik (sebagai kondisi akhir) h. Membandingkan kondisi awal dengan kondisi akhir dan merancang program lanjutan.

6. Pengembangan

a. Menetapkan nilai kedisiplinan yang akan dikembangkan

b. Menemukan cara-cara baru dalam mengembangkan nilainilai kedisiplinan

c. Memperkaya sarana dan prasarana yang mendukung pelaksanaan nilai kedisiplinan yang dipilih

d. Meningkatkan komitmen dan kesadaran masyarakat untuk mendukung program penanaman sikap disiplin

Salah satu upaya yang tepat untuk menanamkan sikap disiplin pada anak adalah dengan menerapkan metode modeling. Pendekatan tersebut dirasa cukup efektif untuk menerapkan nilai-nilai tertentu pada anak usia dini. Dengan modeling siswa akan lebih mudah mengimplementasikan ilmu yang dipelajari serta dapat membangun hubungan harmonis dengan pengajar sebagai modelnya (Ramadhan, 2012). Oleh karena itu, penanganan sistem di TK Aisyah diberikan dalam bentuk rekomendasi program yang bertujuan meningkatkan sikap kedisiplinan melalui metode modeling untuk siswa TK Aisyah. Program tersebut meliputi pengembangan dalam menanamkan kedisiplinan dengan metode modeling yang dapat diterapkan oleh para guru secara praktis. Kepraktisan tersebut mengacu pada penerapannya yang tidak memerlukan fasilitas-fasilitas baru namun dapat memanfaatkan fasilitas yang sudah ada. Pelaksanaan program akan berjalan 
lebih efektif jika memiliki alur pelaksanaan atau panduan yang jelas, maka disusunlah standar operating procedure (SOP) yang berisi langkah-langkah pelaksanaan program. Selain itu, dalam menerapkan metode yang direkomendasikan guru sebagai sumber belajar utama di sekolah perlu memiliki bekal ketrampilan yang dapat mendukung perkembangan siswa. Maka, untuk mengatasi kelemahan dalam hal kompetensi, diberikan pula rekomendasi berupa rancangan strategi pengembangan sumber daya manusia untuk guru.

Untuk melaksanakan program yang direkomendasikan, sekolah perlu memiliki kesiapan yang meliputi perbaikan sarana prasarana, kompetensi dari para pengajar serta komitmen dari seluruh pihak di sekolah. Sarana yang perlu dipersiapkan antara lain buku panduan kegiatan siswa yang mencakup materi hafalan, doa-doa, aturan kelas tertulis, jadwal piket tertulis untuk guru, buku iqro', memfungsikan kembali sarana audiovisual, dan prasarana berupa ruang untuk praktek sholat. Kompetensi sangat diperlukan oleh pengajar yang akan menjadi model dan sumber utama pembelajaran siswa. Tidak kalah penting adalah komitmen dari semua pihak agar program dapat terlaksana dengan konsisten dan mencapai hasil yang efektif.

\section{SIMPULAN}

Masalah yang ada di TK Aisyah yaitu berkaitan dengan kurangnya sikap disiplin para siswa di sekolah. Perilaku ketidaksiplinan siswa tampak pada saat kegiatan pembelajaran berlangsung baik di kelas maupun luar kelas. Hal tersebut membuat suasana belajar kurang kondusif karena materi yang disampaikan guru kurang maksimal. Faktor yang menyebabkan kurangnya sikap disiplin siswa adalah proses belajar yang tidak menerapkan nilai kedisiplinan, metode pembelajaran yang monoton sehingga kurang menarik bagi siswa, serta kurang kosnsistennya sikap pengajar yang disebabkan tidak adanya acuan perilaku atau prosedur dalam melaksanakan kegiatan. Penanaman nilai kedisiplinan merupakan aspek pembangun kepribadaian anak.Proses pembelajaran merupakan salah satu komponen dari sistem yang ada di TK Aisyah. Faktor lain yaitu pengajar yang kurang memberikan contoh kedisiplinan serta menggunakan metode kurang tepat dalam mendisiplinkan anak.

Oleh karenanya, strategi penanganan yang direkomendasikan berupa rancangan pelaksanaan program

Habituation.Pendekatan tersebut diterapkan dalam kegiatan belajarmengajar yang mencakup kegiatan rutin, kegiatan ekstra, serta kegiatan spontan. Untuk dapat mengoptimalkan pelaknsaannya, diperlukan acuan atau standar perilaku baik untuk guru maupun siswa sehingga program akan berjalan dengan lebih optimal. Maka, disusunlah Standart Operating Procedure (SOP) yang merupakan panduan pelaksanaan program. Selain itu, diberikan pula rancangan program pengembangan SDM untuk membekali guru dengan ketrampilan. Pengembangan SDM diperlukan bagi guru untuk mendukung keefektifan metode pembiasaan dan keteladanan.

Sebelum program dterapakan langsung, kepala sekolah sebagai pengambil kebijakan sekolah terlebih dahulu mengkaji program tersebut sehingga kemudian dapat melakukan sosialisasi pada guru sebagai pelaksana program. Kemudian, 
komponen penting lain yaitu siswa dan wali murid yang perlu mendapatkan sosialisasi dari pihak sekolah sebelum pelaksanaan program agar terjadi kesepakatan dan dapat mendukung keefektifan program nantinya.

Beberapa hal yang dapat mendukung penanganan adalah : adanya keterbukaan dari pihak sekolah untuk menerima masukan demi kemajuan sekolah, strategi penanganan berupa langkah-langkah yang bersifat praktis sehingga ebih mudah untuk dilakukan, serta adanya kewenangan dari pihak sekolah untuk menerapkan kebijakan secara mandiri tanpa menentang aturan atau kebijakan yang sudah ada dari pusat. Fasilitas yang telah dimiliki sekolah juga dapat mendukung untuk terlaksananya rekomendasi. Sementara itu, hal yang mungkin menghambat pelaksanaan penanganan adalah : keterbatasan waktu dari para guru, adanya tuntutan dari orang tua yang kadang bertentangan dengan prinsip pendidikan anak usia dini, sehingga berpikir bahwa apa yang ada selama ini sudah tanpa menyadari perlu adanya penanaman nilai kedisiplinan pada perilaku anak.

\section{DAFTAR PUSTAKA}

Aristowati. (2012). Strategi Pembelajaran Disiplin Pada Anak TK Di Kecamatan Boja Kabupaten Kendal. Thesis. Semarang : Universitas Negeri Semarang

John, E. (2011). Upaya Meningkatkan Kedisiplinan Anak di Kelas melalui Cerita. Jurnal Pendidikan Penabur, No 16/ tahun ke 10

Lindawati, F. (2011). Pelaksanaan metode keteladanan dalam membina akhlak anak di RA Nurussibyan randugarut tahun peajaran 2011/1012. Skripsi. Semarang : IAIN Walisongo

Megawangi, R. (2010).Strategi dan Implementasi Pendidikan Karakter pada Anak Usia Dini. Makalah. Bogor: Kementerian Pendidikan Nasional

Murdiono, M. Metode penanaman nilai moral untuk anak usia dini. Ringkasan Skripsi. Yogyakarta : Universitas Negeri Yogyakarta

Nurhayati, I. (2012). Hubungan Pola Asuh Orang tua dengan Kedisiplinan Anak Usia Prasekolah (3-5 tahun) di PAUD Annida Kersan Pegandon Kendal. Skripsi. Semarang : Universitas Muhammadiyah

Puji, D. Peningkatan Kemampuan Disiplin Pada Anak Usia Dini Melalui Kegiatan Bermain Peran di RA Muslimat NU Mafatihul Islamiyah Dwi Puji Rahayuningsih. Jurnal IImiah PG-PAUD IKIP Veteran Semarang

Raharjo, F. (2013). Hubungan Partisipasi Mengikuti kegiatan ekstrakurikuler dan kedisiplinan belajar dengan kemandirian belajar siswa sekolah menengah atas negeri 1 Boyolali tahun ajaran 2013/2014. Skripsi.

Ramadhan, M. (2012). Metode Keteladanan (Uswah) Dalam Pendidikan Islam. Jakarta : Bumi Aksara 
Rahmayani, A. (2013). Teori Albert Bandura (Modeling). diakses dari http://12008ars.blogspot.com/2013/06/teori-albert-bandura-modeling.html?m=1

Wahyuni, S. (2011). Pelaksanaan metode pembiasaan dalam pembelajaran pengembangan agama Islam di Taman Kanak-kanak A Drono IV Ngawen Klaten pada tahun 2010/2011. Skripsi. Semarang : IAIN Walisongo

Wirma, N. (2010). Pelaksanaan penanaman disiplin pada anak dia taman kanakkanak ADHY AKSA XXVI. Jurnal Pesona PAUD. 